\title{
Application times and doses of bovine and sheep biofertilizers in the morphophysiological characteristics of green pepper plants
}

\author{
Épocas de aplicação e doses de biofertilizantes bovino e ovino nas características
} morfofisiológicas de plantas de pimentão

\author{
Y. H. Leal ${ }^{1}$; T. J. Dias ${ }^{2}$; A. C. Bezerra ${ }^{1 *}$; M. P. S. Leal ${ }^{1}$; A. S. Lopes ${ }^{1}$; J. G. \\ Moura $^{1}$; J. E. S. Ribeiro ${ }^{1}$; A. G. Souza ${ }^{1}$ \\ ${ }^{1}$ Departamento de Fitotecnia e Ciências Ambientais, Universidade Federal da Paraíba, 58397-000, Areia- Paraíba, \\ Brazil \\ ${ }^{1}$ Departamento de Agricultura, Universidade Federal da Paraíba, 58220-000, Bananeiras- Paraíba, Brazil \\ *acbezerra78@gmail.com
}

(Recebido em 20 de dezembro de 2019; aceito em 21 de setembro de 2020)

\begin{abstract}
This study aimed to evaluate the morphological characteristics and leaf area of Solário hybrid green pepper plants under different doses and times of application of organic fertilizers based on manure and enriched organic compounds. Two experiments were carried out with applications of organic fertilizers based on manure and enriched organic compounds, using bovine manure (CBF) and sheep manure (SBF). A randomized block experimental design was used was in factorial scheme 4 × $3+1$, with three replications, composed by the doses of biological fertilizers $\left(100,200,300\right.$ and $\left.400 \mathrm{dm}^{3} \mathrm{ha}^{-1}\right)$, application times $(0,30$ and 60 days after transplantation - DAT) and control. The following variables were evaluated: plant height (AP); canopy width (LC); stem diameter (DC); leaf number (NF); leaf length (CF); leaf width (LF); and leaf area (PA). The dose of $100 \mathrm{~g} \mathrm{~L}^{-1}$ of Bovine biofertilizer (CBF) applied at 30 and 60 DAT is indicated for hybrid green peppers cv Solário cultivation since it promoted greater expansion of leaf area. Bovine and sheep fertilizer are indicated to promote plant height, canopy width, stem diameter and number of leaves in hybrid green pepper cv Solário plants.

Keywords: Capsicum annuиm, biological fertilization, organic fertilization.
\end{abstract}

Objetivou-se analisar características morfológicas e a área foliar de plantas do pimentão híbrido Solário sob doses e épocas de aplicação de adubos biológicos à base de esterco e composto orgânico enriquecido. Foram realizados dois experimentos com aplicações de adubos biológicos preparados à base de esterco e composto orgânico enriquecido, um utilizando esterco bovino (CBF) e outro, esterco ovino (SBF). O delineamento experimental utilizado foi em blocos casualizados, em esquema fatorial 4 x $3+1$, com três repetições, referente a doses dos adubos biológicos $\left(100,200,300\right.$ e $\left.400 \mathrm{dm}^{3} \mathrm{ha}^{-1}\right)$, épocas de aplicação (0, 30 e 60 dias após o transplantio - DAT) e a testemunha absoluta. As variáveis avaliadas foram: altura de planta (AP); largura da copa (LC); diâmetro do caule (DC); número de folhas (NF); comprimento de folha (CF); largura de folha (LF); e área foliar (AF). O biofertilizante bovino (CBF) na dose $100 \mathrm{~g} \mathrm{~L}^{-1}$ nas épocas de aplicação 30 e 60 DAT é indicado para cultivo de pimentão híbrido Solário por propiciar maior expansão de área foliar nas plantas. Os biofertilizantes bovino e ovino são indicados na promoção da altura de planta, largura da copa, diâmetro do caule e número de folhas das plantas do pimentão híbrido Solário.

Palavras-chave: Capsicum annuum, adubação biológica, adubação orgânica.

\section{INTRODUCTION}

Green pepper (Capsicum annuum L.) belongs to the Solanaceae family is an annual crop, native from tropical America. It has shrub growth and semi-woody stem that branches out until the end of the plant cycle [1].

This plant stands among the ten Solanaceae plants of greatest economic importance in Brazil [2] and its cultivation is optimized by the use of mineral fertilizers. In order to increase productivity and reduce damage to the environment, especially to the soil, new methods in the agricultural sector have been searched, such as the application of biological or enriched fertilizers. These compounds promote fertilization and addition of organic matter and beneficial microorganisms in the soil, all 
intended to accelerate the process of plant growth, considering, concomitantly, the achievement of better characteristics such as strength, resistance, rusticity, and nutrition [3].

The use of organic compounds of animal origin is a useful and economical practice for small and medium-sized vegetable producers, since it promotes better fertility and soil conservation [4, 5]. However, this practice, when used for several consecutive years, causes the accumulation of organic nitrogen in the soil by increased mineralization potential and availability of this nutrient to the plants.

The determination of nitrogen mineralization rate in soils treated with residues is essential to define the doses to be applied by providing $\mathrm{N}$ to plants at the appropriate time, without losing the element through leaching [3]. These characteristics may ensure greater success in the initial establishment of plants in the field if associated with climatic conditions of the production area which directly influence the physiological and nutritional processes that culminate with the shortening of the production cycle and optimization of the production [6].

Therefore, the objective of this study was to analyze morphological characteristics and leaf area of Solário hybrid green pepper plants under doses and times of application of organic fertilizers based on manure and enriched organic compounds.

\section{MATERIAL AND METHODS}

Two experiments were carried out simultaneously in a commercial cultivation area in the Apolônio Sales Irrigated Perimeter, in Petrolândia, Pernambuco, located in the Semiarid region of Pernambuco state, on the banks of the São Francisco River. The city is located in the "Depression of San Francisco" in which the annual precipitation decreases from southeast to northeast, ranging from 448 to $610 \mathrm{~mm}$ and is characterized by high evaporation and two defined seasons. The average daily temperatures and relative humidity were recorded in the experimental area, with a TH-500 digital Thermo hygrometer, and the precipitation was measured using the TFA 4760 pluviometry (Figure 1).

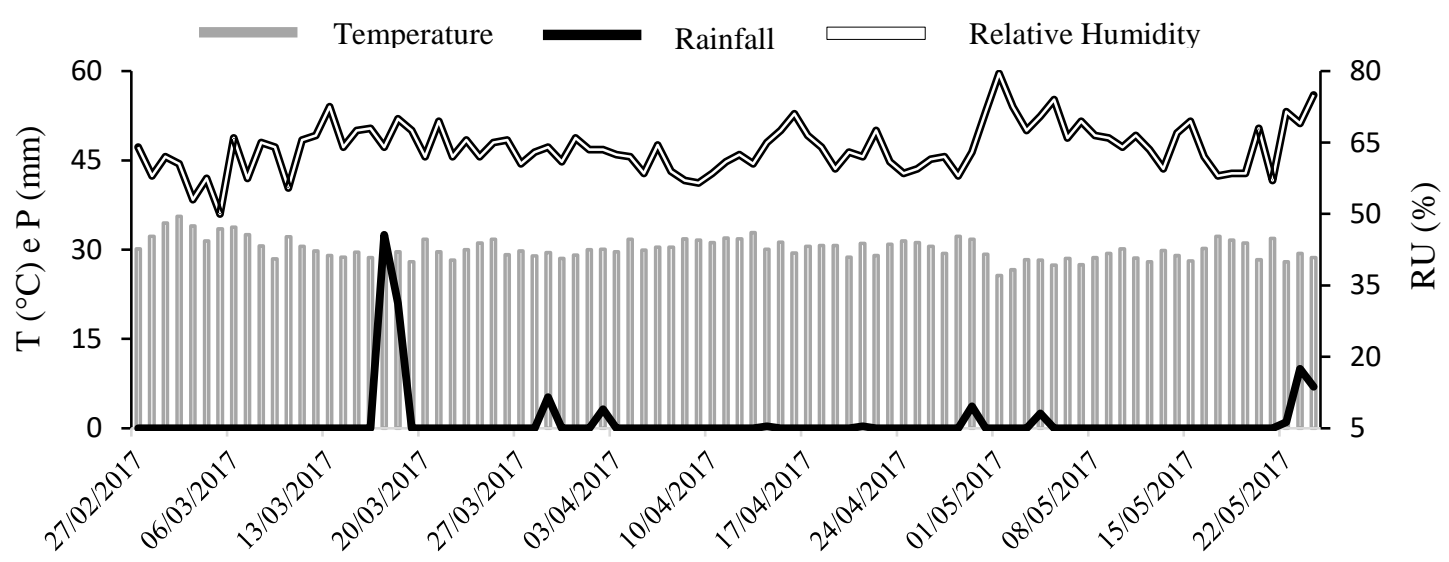

Experimental period

Figure 1: Daily temperature (T), Rainfall $(P)$ and Relative Humidity during the growth period of the hybrid green pepper cv Solário plants (February 27 to May 22) recorded in days after transplantation (DAT) during the experimental period.

The hybrid green pepper cv Solário was used in this study. The seedlings were produced in trays of 128 cells (with cells of $114 \mathrm{~cm}^{3}$ ), containing the commercial substrate Bioplant ${ }^{\circledR}$. At 32 days after sowing (DAS) the transplantation was performed in soil beds in the $1.5 \times 0.5 \mathrm{~m}$ spacing. The soil of the cultivation area is classified as Neosoil Quartzarenic Ortic Latossol [7]; and the soil properties sampled in the layer from 0 to $20 \mathrm{~cm}$, are shown in Table 1 . The analyses were performed at the Soil Laboratory of UFPB, Campus III, Bananeiras-PB. The total organic carbon was 
determined, with values of 8.60 and $6.23 \mathrm{~g} \mathrm{~kg}-1$ for bovine manure (CBF) and sheep manure (SBF), respectively.

Table 1: Chemical properties of the soil used in the cultivation of the hybrid green pepper cv Solário.

\begin{tabular}{|c|c|c|c|c|c|c|c|c|c|c|c|c|c|}
\hline \multirow{2}{*}{$\begin{array}{c}\text { Soil } \\
\text { Sample }\end{array}$} & pH & $\mathbf{P}$ & $\mathbf{K}^{+}$ & $\mathbf{N a}^{+}$ & $\mathrm{H}^{+}+\mathrm{Al}^{+3}$ & $\mathbf{A l}^{+3}$ & $\mathrm{Ca}^{+2}$ & $\mathrm{Mg}^{+2}$ & SB & CEC & V & m & O.M \\
\hline & $\begin{array}{c}\mathrm{H}_{2} \mathrm{O} \\
(1: 2,5)\end{array}$ & \multicolumn{2}{|c|}{$\mathrm{mg} \mathrm{dm} \mathrm{m}^{-3}$} & & & \multicolumn{2}{|c|}{$\mathrm{Cmol}_{\mathrm{c}} \mathrm{dm}^{-3}$} & & & & $-\%$ & - & $\mathrm{g} \mathrm{kg}^{-1}$ \\
\hline CBF & 6,95 & 388,01 & 152,88 & 0,12 & 3,47 & - & 3,50 & 1,50 & 5,51 & 8,98 & 61,40 & - & 10,73 \\
\hline SBF & 6,81 & 497,50 & 155,22 & 0,10 & 3,14 & - & 3,50 & 1,10 & 5,10 & 8,23 & 61,92 & - & 14,83 \\
\hline
\end{tabular}

$\mathrm{H}^{+}+\mathrm{Al}^{+3}$ : Potential Acidity; SB: sum of Basis; CTC: Cation exchange capacity; V: Saturation of basis; m: Saturation through aluminium; O.M: Organic Matter.

At five days after transplantation (DAT) $80 \mathrm{Mg}$ ha-1 of urea was applied, and at 7 days $130 \mathrm{Mg}$ ha-1 of the NPK formulation 06-24-12 was applied, whereas, at 37 DAT, $260 \mathrm{Mg}$ ha-1 of the NPK formulation 20-10-20 was applied. Dripping system irrigation was used and the water chemical properties are shown in Table 2. The water supply came from the São Francisco River and the average daily water volume applied was $9.12 \mathrm{~mm}$ per plant, fractioned into two applications of 4.56 $\mathrm{mm}$ each, early in the morning and late afternoon. The water analysis was performed at the Soil Analysis Laboratory of UFPB, Campus II, Areia-PB.

Table 2: Chemical properties of the water used in irrigation during the cultivation of hybrid green pepper cv Solário.

\begin{tabular}{|c|c|c|c|c|c|c|c|c|c|c|c|c|}
\hline pH & E.C & $\mathrm{SO}_{4}^{-2}$ & $\mathrm{Mg}^{2+}$ & $\mathbf{N a}^{+}$ & $\mathbf{K}^{+}$ & $\mathrm{Ca}^{2+}$ & $\mathrm{CO}_{3}{ }^{-2}$ & $\mathrm{HCO}_{3}^{-2}$ & Cl & RAS & CSP & Classification \\
\hline & $\mathrm{dS} \mathrm{m} \mathrm{m}^{-1}$ & $m g L^{-1}$ & & & & $\mathrm{~mm}$ & $\mathrm{~L}^{-1}$ & & - & & & \\
\hline 6,7 & 0,09 & 0 & 0,18 & 0,2 & 0,1 & 0,1 & 0 & 1,2 & 0,3 & 0,6 & 0 & $\mathrm{C}_{1} \mathrm{~S}_{1}$ \\
\hline
\end{tabular}

E.C: Electrical conductivity at $25^{\circ} \mathrm{C}$; RAS: Relation of Sodium Adsorption; CSP: Changeable Sodium Percentage. $\mathrm{C}_{1} \mathrm{~S}_{1}$ : Richards (1954)[8].

Two independent experiments were carried out in this study. In the first experiment, applications of biological fertilizers were applied, prepared based on manure and enriched organic compound, using bovine manure $(\mathrm{CBF})$. In the second experiment, applications of biological fertilizers were applied, and the fertilizers were prepared based on manure and organic compound enriched with sheep manure (SBF).

The preparation of biological fertilizers followed the recommendations of the manufacturer, and two biofactories (polyethylene water boxes with lids) with a capacity of 100 liters each were used. The enriched organic compound presents recalcitrant substances, biodynamic compounds, pentoses, minerals, and bran [9]. Each biofactory was filled with five kilograms of enriched organic compound, 15 liters of manure (bovine or sheep), and the remaining volume completed with untreated water, corresponding to the proportions of 5 and $15 \%$ of enriched organic compound and manure, respectively.

Every three days the biological fertilizer was stirred with the aid of a wooden shovel and left for anaerobic fermentation for 15 days [9]. The application of biological fertilizers was made on the soil surface, using a manual spray with a capacity of five liters, and the pre-filtration of the organic input was performed with the aid of a sieve with a mesh of $2 \mathrm{~mm}$ in diameter. Chemical analyses of biological fertilizers (Table 3) were performed at the Plant Tissue Analysis Laboratory of UFPB, Campus II, Areia-PB.

A randomized block experimental design was used in both experiments, in a factorial scheme $((4 \times 3)+1)$, with three replications, composed by the doses of the biological fertilizers $(100,200$, 300 and $400 \mathrm{dm}^{3}$ ha-1), application times (0,30 and 60 DAT) and the control (with no application of fertilizer), summing 13 treatments. The experimental plot consisted of four rows of four meters 
each, corresponding to an area of $24 \mathrm{~m}^{2}$, with 32 plants. The useful area was $6 \mathrm{~m}^{2}$, composed of two central rows, two plants from the ends of each row were excluded, summing 8 plants.

Table 3: Chemical properties of the bio-fertilizers applied in the cultivation of the hybrid green pepper $c v$ Solário.

\begin{tabular}{|c|c|c|c|c|c|c|c|c|c|c|c|c|c|c|}
\hline Biofertili & $\mathbf{U}$ & $\mathrm{CO}$ & $\mathbf{N}$ & $\mathbf{P}$ & $\mathbf{K}$ & $\mathbf{C a}$ & Mg & $\mathbf{S}$ & $\mathrm{Na}$ & $\mathrm{Cu}$ & $\mathbf{Z n}$ & $\mathbf{F e}$ & Mn & B \\
\hline zer & - & $6-$ & & & & $\mathrm{g} \mathrm{L}^{-1}$ & & & & - & - & $\mathrm{mg} \mathrm{L}^{-}$ & & - \\
\hline CBF & 98,7 & 10,4 & 0,1 & 0,08 & 30,9 & 0,22 & 0,58 & 0,05 & - & 0,43 & 0,61 & 5,12 & 0,62 & 2,22 \\
\hline SBF & 98,8 & 11,1 & 0,11 & 0,07 & 24,3 & 0,15 & 0,27 & 0,07 & - & 0,46 & 0,54 & 10,6 & 0,51 & 2,13 \\
\hline
\end{tabular}

CBF: Biofertilizer made with bovine manure; SBF: Biofertilizer made with sheep manure; U: Humidity; CO: Dichromate oxidation method; N, P, K, Ca e Mg: Digestion with $\mathrm{H}_{2} \mathrm{O}_{2}$ e $\mathrm{H}_{2} \mathrm{SO}_{4}$; $\mathrm{S}, \mathrm{Fe}, \mathrm{Cu}, \mathrm{Mn}, \mathrm{Zn}$ e Na: Digestion with $\mathrm{HNO}_{3}$ $\mathrm{HCLO}_{4}$; B: Extraction through dry combustion.

For the application time, in treatments 1 to 4 , the doses of biological fertilizers were fully applied on the day of transplantation (0 DAT), in treatments 5 to 8 the doses were fractionated twice, at 0 and $30 \mathrm{DAT}$, and in treatments 9 to 12 the doses were fractioned three times, with applications at 0,30 and 60 DAT (Table 4).

Table 4: Details of treatments applied at different times and doses of the bio-fertilizers.

\begin{tabular}{ccccc}
\hline Treatments & Application time (DAT) & 0 & 30 & 60 \\
\cline { 2 - 5 } 1 & 0 & \multicolumn{3}{c}{ Doses in $\mathrm{dm}^{3} \mathrm{ha}^{-1}$} \\
2 & 0 & 200.00 & & \\
3 & 0 & 300.00 & & \\
4 & 0 & 400.00 & & \\
5 & 30 & 50.00 & 50.00 & \\
6 & 30 & 100.00 & 100.00 & \\
7 & 30 & 150.00 & 150.00 & \\
8 & 30 & 200.00 & 200.00 & \\
9 & 60 & 33.33 & 33.33 & 33.33 \\
10 & 60 & 66.66 & 66.66 & 66.66 \\
11 & 60 & 100.00 & 100.00 & 100.00 \\
12 & 60 & 133.33 & 133.33 & 133.33 \\
13 & Control & 0.00 & 0.00 & 0.00 \\
\hline
\end{tabular}

At 87 DAT, the plant height (AP) was evaluated, measured from the soil surface to the apex of the plant; the canopy width (LC); the stem diameter (DC), measured 3 centimeters above soil level; the number of leaves (NF); leaf length (CF), measuring the maximum length of the mid rib; leaf width (LF); and leaf area (PA), using the equation: $\mathrm{AF}=\mathrm{K}+\mathrm{L}+\mathrm{C}$, in which $\mathrm{K}$ is the correlation coefficient (0.60) recommended by [10], $\mathrm{L}$ is the width and $\mathrm{C}$ the length of the leaf. To execute the evaluations, digital calipers, rulers, and graduated measuring tapes were used.

For both experiments, the data were submitted to the normality test (Shapiro-Wilk) and homogeneity (Bartlett), and then submitted to variance analysis. When they presented significant differences by the $\mathrm{F}$ test, the mean test (Tukey test at a 5\% probability) for qualitative factors and regression analysis for quantitative factors was used. To compare the combinations of the factors with additional treatment, the Dunnet test was performed at 5\% probability. The $\mathrm{R}$ statistical software was used [11] with the packages ExpDes [12] and multcomp [13]. 


\section{RESULTS AND DISCUSSION}

The variables leaf length (CF), leaf width (LF), and leaf area (PA) presented an isolated effect for the biological fertilizer factor, where the biofertilizer enriched with bovine manure (CBF) in its composition, showed improvement in the morphological characteristics of the plants.

Nevertheless, other sources of variations and their interactions did not present significant results for the other variables evaluated. By the Dunnet test, no differences were verified between the variables that showed significance in variance analysis and additional treatment.

At 87 DAT, the survival rate of the plants was $100 \%$ in both experiments. It was verified for the leaf length $(\mathrm{CF})$ of the plants treated with the organic fertilizer enriched with bovine manure (CBF) (Figure 2A) presented more than 5\% in CF gain when compared with biological fertilizers enriched with sheep manure (SBF), at 30 and 60 DAT at dose $200 \mathrm{~L} \mathrm{ha}^{-1}$ (Figure $2 \mathrm{~B}$ ). This gain may be the result of an improvement in cationic exchange capacity (CTC), which is responsible for the retention and prolongation of nutrient availability over the period [14].

However, a positive response was also verified with the dose of $300 \mathrm{~L} \mathrm{ha}^{-1}$ of CBF (Figure 2B), with a $10.1 \%$ gain in CF compared with biological fertilizer SBF. This increase was probably due to adequate dosage as well as the combination between the continuous supply of nutrients in the plant and the edaphic or climatic factors of the local area, such as solar radiation and temperature (Figure 1), promoting higher photosynthetic efficiency and the production of new tissues in the organs of the plant [6].
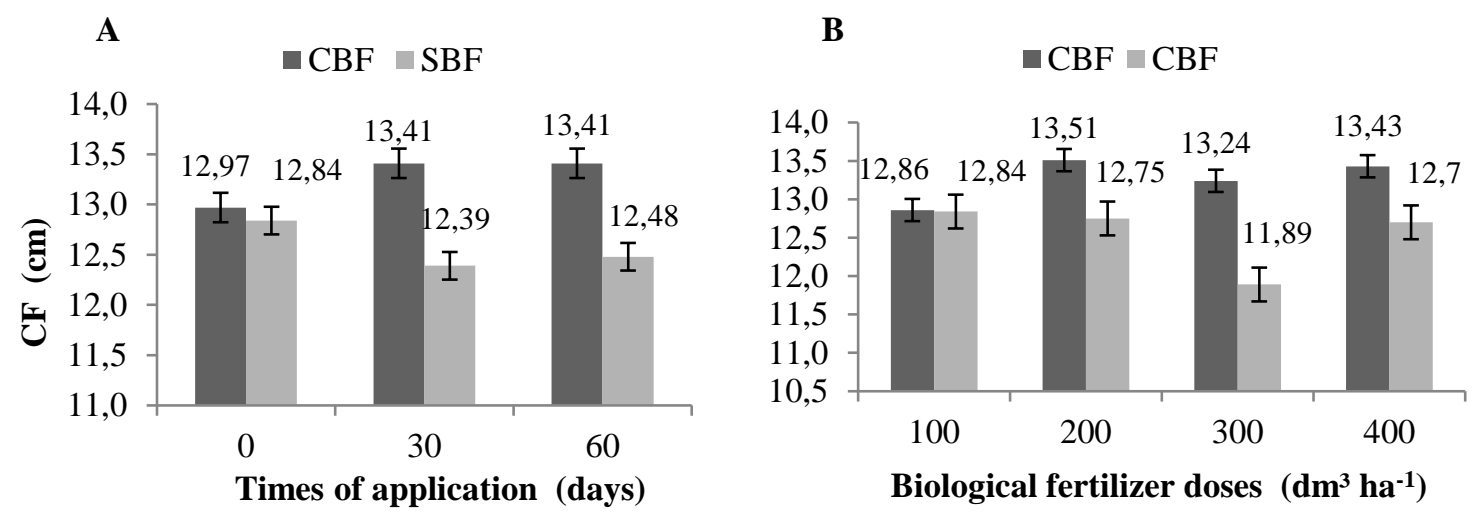

Figure 2: Leaf length of hybrid green pepper cv Solário plants under different application times (A) and doses of biological fertilizers enriched with bovine manure $(C B F)$ and sheep manure $S B F(B)$ under field condition.

Considering the leaf width variable (LF) isolated, the application at 60 of CBF DAT (Figure 3A) shows a tendency of more energy investment in the expansion of LF, that is, the plant can change the partition of assimilated. Thus, the preferred drains of consumption and storage of mineral and photoassimilates nutrients become those seen in the aerial part, such as expanding leaves [15], a fact observed in the plants of the hybrid green pepper cv Solário at 60 DAT. 
A

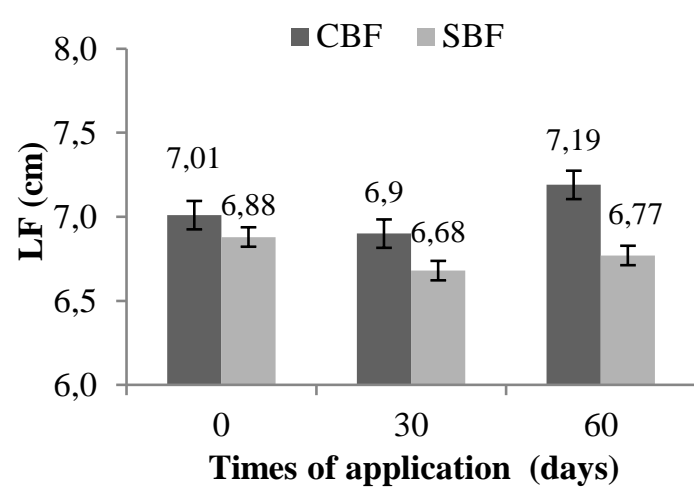

B

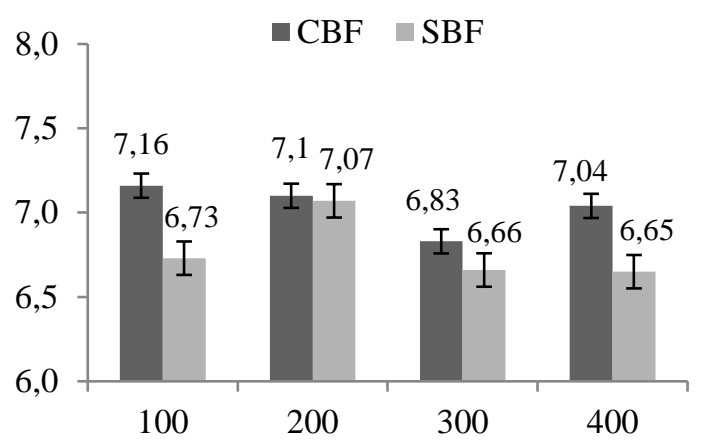

Biological fertilizer doses $\left(\mathbf{d m}^{3} \mathbf{h a}^{-1}\right)$

Figure 3: Leaf width of hybrid green pepper cv Solário plants under different application times $(A)$ and doses of biological fertilizers enriched with bovine manure $(C B F)$ and sheep manure $S B F(B)$ under field condition.

Plants that received the dose of $200 \mathrm{~L} \mathrm{ha}^{-1}$ of CBF or SBF had very similar responses for the variable $\mathrm{LF}$ (Figure 3B). In practical terms, the $100 \mathrm{~L} \mathrm{ha}^{-1}$ dose of CBF biological fertilizer (Figure 3B) showed a positive influence on the leaf width of the green pepper plants.

For the leaf area, higher values were also obtained for the green pepper plants at the times of 30 and 60 DAT with the application of CBF enriched biological fertilizer (Figure 4A), especially at the dose of $100 \mathrm{~L} \mathrm{ha}^{-1}$ (Figure 4B).

The increase in leaf area at the time of 30 and 60 DAT is directly correlated to the increase in the number of leaves per plant [16], which provides greater efficiency in photosynthetic carbon assimilation [17], which in turn, has a direct relationship with the availability of energy to optimize growth in the initial stage of plant development [18], a fact that was indeed observed in the plants of the hybrid green pepper cv Solário (Figures 4 A-B and Figures 5 G-H).

At the dose of $100 \mathrm{~L} \mathrm{ha}^{-1}$, an increase in the leaf area was also observed due to the higher nutrient content present in the CBF (Table 3), a fact confirmed by [19,20], they state that the leaf area is greater when the nutrient content in the organic fertilizer is increased. The higher $\mathrm{P}$ content found in $\mathrm{CBF}$ also contributed to the increment in the leaf area of the plants in this study, considering that this macronutrient favors increasing of leaf area per unit of total mass, which contributes to increase the capacity for $\mathrm{CO} 2$ assimilation [21].

Hybrid green peppers cv Solário plants fertilized with CBF enriched biological fertilizer at the dose of $100 \mathrm{~L} \mathrm{ha}^{-1}$ had $23.74 \%$ less AF expansion when compared with CBF enriched biological fertilizer (Figure $4 \mathrm{~B}$ ), this happens due to the fact of the low availability of $\mathrm{Mg}^{2+}$ in SBF enriched biological fertilizer (Table 3). According to Souza et al. (2020) [22], $\mathrm{Mg}^{2+}$ has a central connection with the chlorophyll molecules. However, the low availability of this nutrient can reduce carbon fixation, and result in restrictions on carbohydrate production that would serve as a substrate for the synthesis of new organic molecules, as well as for plant respiration. 


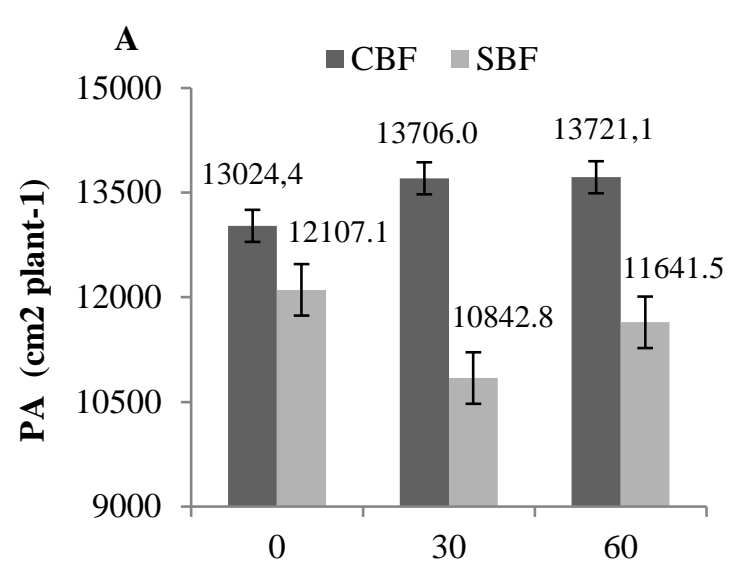

Times of application (days)

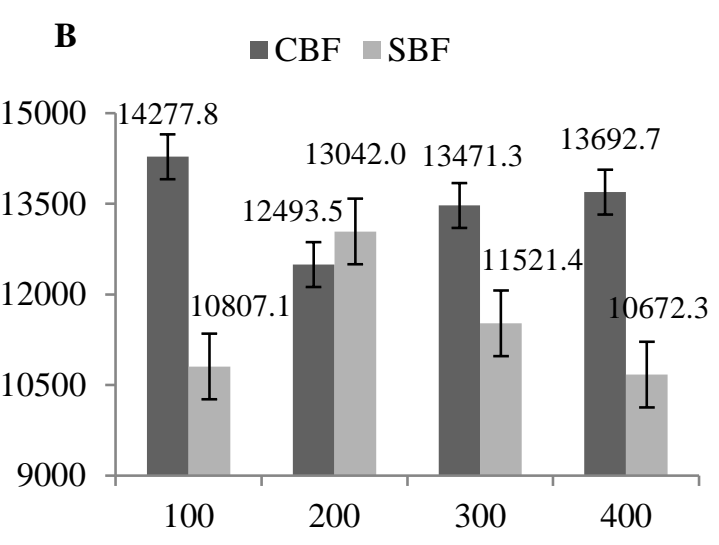

Biological fertilizer doses $\left(\mathbf{d m}^{3} \mathbf{h a}^{-1}\right)$

Figure 4: Leaf area of hybrid green pepper cv Solário plants under different application times (A) and doses of biological fertilizers enriched with bovine manure $(C B F)$ and sheep manure $S B F(B)$ under field condition.

Morphological attributes such as PA is generally related to the length and width of the leaf, a fact evidenced by Borges et al. (2011)[23], and the maxima AP of green pepper plants studied by the authors was $4,323.8 \mathrm{~cm}^{2}$ per plant at 72 DAT in an organic system. While in the present study, the PA was $13,483.86 \mathrm{~cm}^{2}$ per plant with CBF enriched biological fertilizer, promoting a three times higher increase in the leaf area of the plants when compared to the ones grown in the organic system.

In the present work, the application of biological fertilizers did not provide any significant effect in plant height (AP), canopy width (LC), stem diameter (CD) and number of leaves (NF) (Figures 5 A-H). Probably because the cultivar used (Solário) has an excellent growth pattern and also because the amount of nutrients available in the cultivation area (Table 1) and the enriched biological fertilizers CBF and SBF (Table 3) was within an adequate range to meet the nutritional requirements of the plants. 


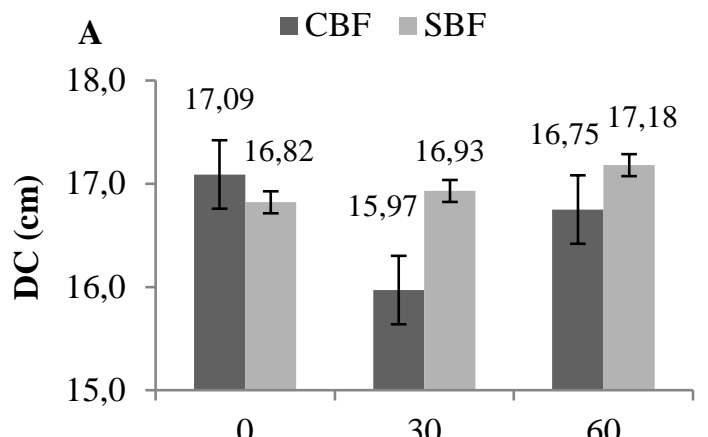

Times of application (days)

C

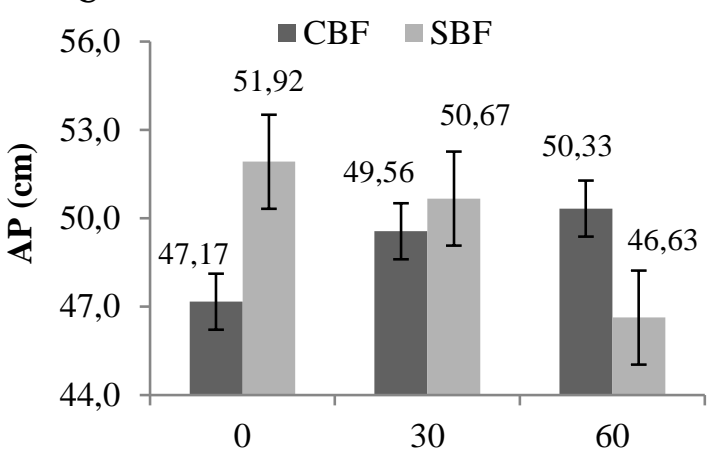

Times of application (days)

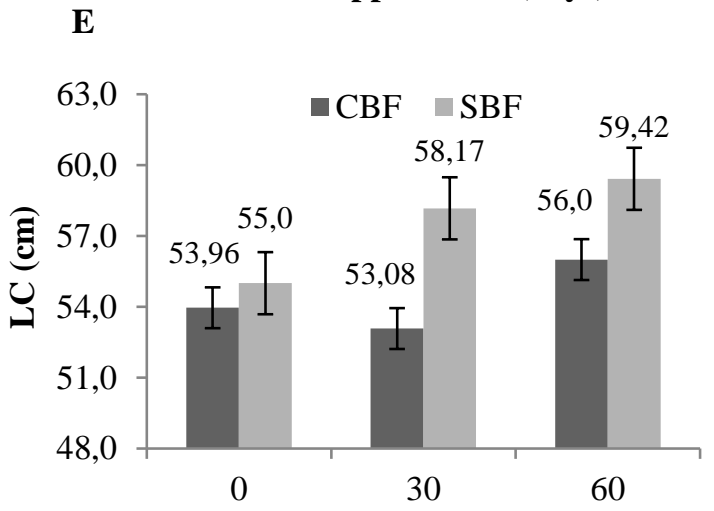

Times of application (days)

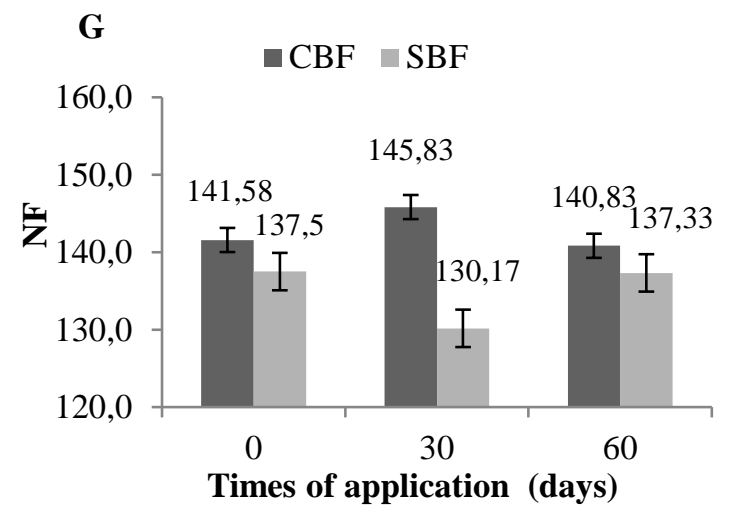

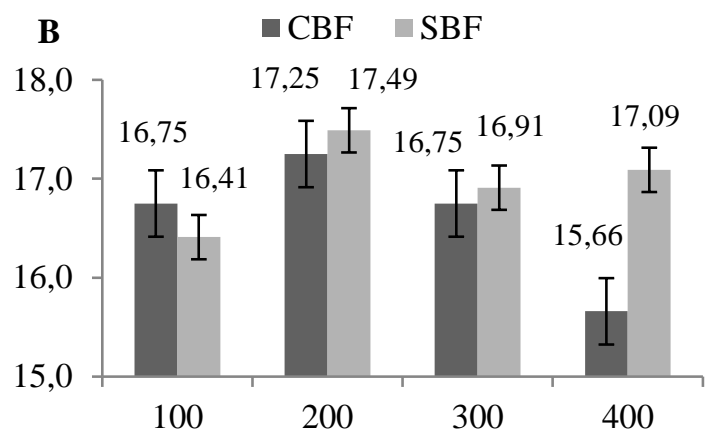

Biological fertilizer doses $\left(\mathrm{dm}^{3} \mathrm{ha}^{-1}\right)$

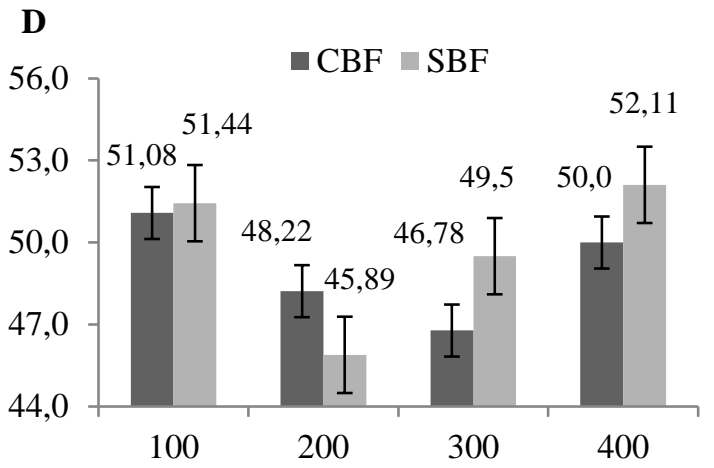

Biological fertilizer doses $\left(\mathrm{dm}^{3} \mathrm{ha}^{-1}\right)$

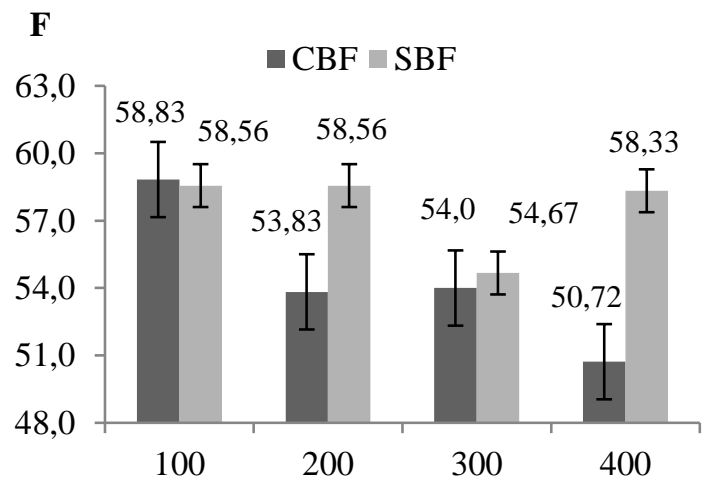

Biological fertilizer doses $\left(\mathrm{dm}^{3} \mathrm{ha}^{-1}\right)$

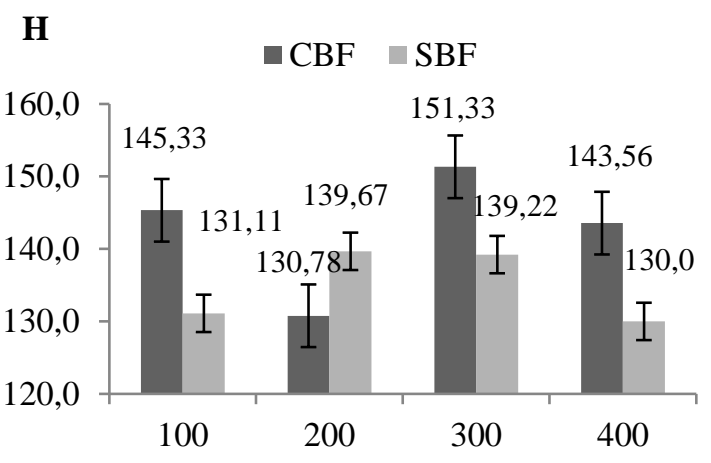

Biological fertilizer doses $\left(\mathrm{dm}^{3} \mathrm{ha}^{-1}\right)$

Figure 5: Stem diameter (DC), Plant height (AP), canopy width (LC) and number of leaves (NF) of hybrid green pepper $c v$ Solário plants under different application times $(A, C$ and $E)$ and doses of biological fertilizers enriched with bovine manure $(C B F)$ and sheep manure $(S B F)(B, D$ and $F)$, under field condition. 
According to Tables 1 and 3, the $\mathrm{K}$ concentrations are within the appropriate range for green pepper plants [24]. According to Menegatti et al. (2019)[25], K is an element capable of promoting high water retention in plant tissues, which induces the largest cell turgor, boosting and resulting in superiority in stem thickening. Sediyama et al. (2014)[2] evaluated the nutrition and fruit yield in two colorful green pepper cultivars; Amanda (yellow) and Rubia (red) fertilized with swine biofertilizer via soil and considered as an adequate range for potassium nutrient in soil $178 \mathrm{mg} \mathrm{dm}$ 3 in addition to $10.92 \mathrm{~g} \mathrm{~L}^{-1}$ of swine biofertilizer.

Also, in the present study, the K content present in the soil (Table 1) is within the range proposed by Sediyama et al. (2014)[2] as well as the concentration in the biological fertilizer CBF and SBF (Table 3). Since, according to D'avila et al. (2011)[26], $\mathrm{K}$ is an element capable of promoting high water retention in plant tissues, which induces the largest cell turgor, boosting and resulting in higher stem thickening. Therefore, the absence of the effect on the hybrid green pepper cv Solário plants cultivated with both $\mathrm{CBF}$ and SBF biological fertilizer in the stem diameter (Figures $5 \mathrm{~A}$ and B) is justified.

One of the main nutrients responsible for plant growth is Nitrogen. Inadequate concentrations it directly influences the production of proteins, amino acids, enzymes, indispensable to the production of non-structural carbohydrates, including starch and soluble sugars (sucrose, glucose, fructose, and sorbitol), molecules that play an essential role in the growth of the vegetables, providing structural components to form new cells and, consequently, a maximum production of biomass [15].

This fact was observed in the present study with the use of the biological fertilizers CBF and SBF, which were sufficient to meet the demand for nutrients in the plants of the hybrid green pepper cv Solário, and promoted similar values (Figures $5 \mathrm{~B}, \mathrm{D}$, and F) for the variables plant height (AP) and canopy width (LC).

\section{CONCLUSIONS}

The bovine biofertilizer (CBF) at the dose $100 \mathrm{~g} \mathrm{~L}^{-1}$ applied at 30 and $60 \mathrm{DAT}$ is recommended in the cultivation of the hybrid green peppers cv Solário since it provided greater expansion of leaf area.

The bovine and sheep fertilizer are recommended since they promote higher plant height, canopy width, stem diameter, and number of leaves in plants of the hybrid green pepper cv Solário.

\section{REFERENCES}

1. Mortate RK, Araújo MM, Lima MWP, Binotti FFS. Resposta de mudas de pimentão submetidas à diferentes reguladores vegetais via foliar. Rev CTA. 2018;10(1):57-64.

2. Sediyama MAN, Marlei RS, Vidigal SM, Pinto CLO, Jacob LL. Nutrição e produtividade de plantas de pimentão colorido, adubadas com biofertilizante de suíno. Rev bras eng agríc ambient. 2014;18(6):588594, doi:10.1590/S1415-43662014000600004

3. Moretti SML, Bertoncini EI, Abreu Júnior CH. Aplicação do método de mineralização de nitrogênio com lixiviação para solo tratado com lodo de esgoto e composto orgânico. Rev Bras Ciênc Solo. 2013;37(2): 622-631, doi:10.1590/S0100-06832013000300008

4. Araújo EM, Oliveira AP, Cavalcante LF, Pereira WE, Brito NM, Neves CML, Silva EE. Produção do pimentão adubado com esterco bovino e biofertilizante. Rev bras eng agríc ambient. 2007;11(5):466470, doi:10.1590/S1415-43662007000500003

5. Alves LS, Véras MLM, Melo Filho JS, Irineu THS; Dias TJ. Salinity in irrigation water and application of bovine biofertilizer for growth and quality of tamarindo seedlings. Irriga. 2019;24(2):254-273.

6. Porto TB, Soares VN, Reis BB, Almeida AS, Rodrigues DB, Tunes LM. Parâmetros de crescimento de plântulas de pimentão na semeadura em diferentes substratos. Rev Fac Agron. 2018;117(1):69-76.

7. Embrapa. Sistema Brasileiro de Classificação de Solos. Centro Nacional de Pesquisa de Solos (Rio de Janeiro, RJ). Brasília: Embrapa-SPI. 2006. 306 p.

8. Richards LA. Diagnosis and improvement of saline and alkali soils. Washington D.C.: U.S. Salinity LSBFratory. 1954. $160 \mathrm{p}$.

9. Microgeo. Manual técnico. Microgeo - Adubação biológica, 24 p. Disponível em: http://microgeo.com.br/site/front/img/manual_tecnico.pdf. Data de acesso: 10 de dezembro de 2019. 
10. Tivelli SW, Mendes F, Goto R. Estimativa da área foliar do pimentão (Capsicum annum L.) cv. Elisa conduzido em ambiente protegido. Hort bras. 1997;15.

11. R CORE TEAM. R: A language and environment for statistical computing. Viena, AU: R Foundation for Statistical Computing. 2018. 2673 p.

12. Ferreira EB, Cavalcanti PP, Nogueira DA. Package 'ExpDes.pt': Experimental Designs. R package version 1.2.0. 2018. $62 \mathrm{p}$.

13. Hothorn T, Bretz F, Westfall P. Simultaneous Inference in General Parametric Models. Biom J. 2008;50(3):346-363, doi:10.1002/bimj.200810425

14. Sousa EG, Silva TI, Dias TJ, Ribeiro DV, Gonçalves Neto ÁC, Sousa LV, Gonçalves AC M, Moura JG, Melo Filho JS, Biological fertilization as an attenuation of salinity water on beetroot (Beta vulgaris). J Agric Sci. 2018;10(7):85-94, doi:10.5539/jas.v10n7p85

15. Taiz L, Zeiger E, Moller I, Murphy A. Fisiologia e desenvolvimento vegetal. Porto Alegre: Artmed. 2017. 888 p.

16. Menegatti RD, Guollo K, Navroski MC, Vargas OF. Fertilizante de liberação lenta no crescimento inicial de Aspidosperma parvifolium A. DC. Sci Agrar Paran. 2017;16(4):45-49, doi:10.18188/19831471/sap.v16n1p45-49.

17. Afonso MV, Martinazzo EG, Aumonde TZ, Villela FA. Parâmetros fisiológicos de mudas de Albizia niopoides produzidas em diferentes composições de substrato. Ci Fl. 2017;27(4):1395-1402, doi: $10.5902 / 1980509830221$.

18. Celedonio CA, Medeiros JF, Viana TVA, Saraiva KR, Lima GHP. Área foliar da figueira em três ambientes de cultivo, sob fertirrigação de biofertilizante bovino. Rev Bras Agric. 2016;10(2):586-597.

19. Gopal M., Gupta A, Sunil E, Thomas VG. Amplification of plant beneficial microbial communities during conversion of coconut leaf substrate to vermicompost by Eudrilus sp. Curr Microbiol. 2010;59:15-20.

20. Khandaker M. M, Rohani F, Dalorima T, Mat N. Effects of different organic fertilizers on growth, yield and quality of Capsicum Annuum L. var. Kulai (Red Chilli Kulai). Biosci Biotech Res Asia. 2017;14(1): 185-192, doi:10.13005/bbra/2434

21. Cruz JL, Souza Filho LFS, Pelacani CR. Influência da adubação fosfatada sobre o crescimento do camapu (Physalis angulata L.). Rev Bras P. Med. 2015;17(3):360-366, doi:10.1590/1983084X/13_060.

22. Souza AG, Smiderle OJ, Chagas EA, Alves MS, Fagundes PRO. Growth, nutrition and efficiency in the transport, uptake and use of nutrients in african mahogany. Rev Ciênc Agron. 2020;53(1):11-17, doi:10.5935/1806-6690.20200024

23. Borges FRM, Lage MP, Lima JGA, Guimarães Neto JWA, Pinheiro Neto LG, Viana TVZ. Crescimento do pimentão híbrido amarelo cultivado de forma orgânica sob diferentes ambientes. Cad Agroecologia. 2011;6(2):1-12.

24. Malavolta E, Vitti GC, Oliveira SA. Avaliação do estado nutricional das plantas. Princípios e aplicações. Piracicaba: POTAFOS. 1997. 319 p.

25. Menegatti RD, Souza AG, Bianchi VJ. Growth and nutrient accumulation in three peach rootstocks until the grafting stage. Comunicata Scientiae. 2019;10(4):1-7, doi:10.14295/cs.v10i4.3211

26. D'avila FS, Paiva HN, Leite HG, Barros NF, Leite FP. Efeito do potássio na fase de rustificação de mudas clonais de eucalipto. Rev Árvore. 2011;35(1):13-19, doi: 10.1590/S0100-67622011000100002 